\title{
PENGARUH PENDIDIKAN KEWIRAUSAHAAN DAN MOTIVASI BERPRESTASI TERHADAP MINAT BERWIRAUSAHA MAHASISWA FAKULTAS EKONOMI UNIVERSITAS SEMARANG
}

\author{
Andhy Tri Adrianto \\ Anitiyo Soelistiyono \\ Nyayu Nurkomalasari
}

Diterima: Februari 2019, Disetujui: Maret 2019. Dipublikasikan: April 2019

\begin{abstract}
This study aims to determine to determine the effect of Entrepreneurship Education and the influence of Achievement Motivation Interest in Entrepreneurial Student Faculty of Economics, University of Semarang. Research location at faculty of Economic in University of Semarang. The population used is afternoon students of Semester II of Faculty of Economics, University of Semarang.

The population was the afternoon class students of the 2017/2018 force Semester II Faculty of Economics Management, 314 students of the University of Semarang. Samples taken were 176 respondents. Data sources were used from primary data and secondary data. This type of research is quantitative. Data collection methods use questionnaires, observations and interviews. Data analysis in this study uses Multiple Linear Regression Analysis and classical assumption test using SPSS program application ver 18 for windows. Sampling technique Purposive random sampling

Based on the results of testing the goodness of fit of the two independent variables individually tested the most dominant influence on interest in entrepreneurship at Semarang University is entrepreneurship education (with a coefficient of 0.646). The second dominant variable affecting the interest in entrepreneurship at Semarang University is achievement motivation (with a coefficient of 0.251). Entrepreneurship Education influences Entrepreneurial Interest, the high calculated value of $r$ is Dare to Take Risks of 0.942, for that it needs to be maintained so that with suggestions for improvement, students can be better at improving their entrepreneurial learning achievements. Other indicators such as, innovation with $r$ count 0.907 needs to be improved. Achievement motivation does not affect the interest in entrepreneurship, Hope a task is seen by the responsiveness of the subject, with a count of 0.746, students should be given a soft skill training to be clearer in seeing the potential In him, the high calculated value of $r$ is an attempt to succeed 0.885, for that it needs to be maintained so that with these efforts students can better improve their soft skills. Other indicators, motives for overcoming obstacles and individual ego involvement in a task with calculated ratios of 0.811 and 0.847 , need to be evaluated properly.

Keywords: $\quad$ Entrepreneurship Education, Achievement Motivation, Interest in Entrepreneurship
\end{abstract}

\section{ABSTRAK}

Penelitian ini bertujuan untuk mengetahui Pendidikan Kewirausahaan dan pengaruh Motivasi Berprestasi Kepentingan Mahasiswa Wirausaha Fakultas Ekonomi Universitas Semarang. Lokasi penelitian ini laksanakan di Fakultas Ekonomi Universitas Semarang.

Adapun populasinya adalah siswa kelas sore angkatan 2017/2018 Manajemen Fakultas Ekonomi Semester II, sebanyak 314 mahasiswa Universitas Semarang. Sampel yang diambil adalah 176 responden. Sumber data digunakan dari data primer dan data sekunder. Jenis penelitian ini adalah kuantitatif. Metode pengumpulan data menggunakan kuesioner, observasi dan wawancara. Analisis data dalam penelitian ini menggunakan Analisis Regresi Linear Berganda dan uji asumsi klasik menggunakan aplikasi program SPSS ver 18 for windows. Teknik pengambilan sampel Purposive random sampling

Berdasarkan hasil pengujian goodness of fit dari dua variabel independen yang diuji secara individual pengaruh yang paling dominan terhadap minat berwirausaha di Universitas Semarang adalah pendidikan kewirausahaan (dengan koefisien 0,646). Variabel dominan kedua yang mempengaruhi minat berwirausaha di Universitas Semarang adalah motivasi berprestasi (dengan koefisien 0,251). Pendidikan Kewirausahaan mempengaruhi Minat Wirausaha, nilai hitung yang tinggi adalah Berani Mengambil Risiko 0,942, untuk itu perlu dipertahankan sehingga dengan saran untuk perbaikan, siswa dapat lebih baik dalam meningkatkan prestasi belajar wirausaha mereka. Indikator lain seperti, inovasi dengan 
rhitung 0,907 perlu ditingkatkan. Motivasi berprestasi tidak mempengaruhi minat berwirausaha, Harapan suatu tugas dilihat oleh responsivitas subjek, dengan hitungan 0,746, siswa harus diberikan soft skill training agar lebih jelas dalam melihat potensi yang ada di dalam dirinya, nilai terhitung tinggi $r$ adalah upaya untuk berhasil 0,885 , untuk itu perlu dipertahankan sehingga dengan upaya ini siswa dapat lebih meningkatkan keterampilan lunak mereka. Indikator lain, motif untuk mengatasi hambatan dan keterlibatan ego individu dalam tugas dengan rasio yang dihitung 0,811 dan 0,847, perlu dievaluasi dengan benar.

Kata kunci : Pendidikan Kewirausahaan, Motivasi Berprestasi, Minat dalam Kewirausahaan

\section{PENDAHULUAN}

\section{Latar Belakang}

Penciptaan lapangan kerja dan penyerapan tenaga kerja yang efektif, dan inovatif dapat mendorong kemajuan perekonomian. Sejalan dengan hal tersebut, Olanepikun, Brimah (2015) juga menyatakan bahwa kompetensiChidiebere Iloanya (2014) menyatakan bahwa entrepreneur adalah mesin, ketrampilan dan kemampuan entrepreneur yang dimiliki warga negara sangat berpengaruh pada tingkat kesejahteraan dan pertumbuhan ekonomi negara tersebut.

Subroto (2013) menyatakan bahwa kegagalan suatu negara dalam mengembangkan entrepreneur kepada warga negaranya akan menjadi penyebab dari kemiskinan dan kegagalan secara ekonomi negara yang bersangkutan. Keadaan dimana warga negara memiliki kompetensi, ketrampilan dan kemampuan entrepreneur hanya akan dapat diwujudkan apabila negara menerapkan suatu sistem pendidikan yang menjadikan warga negaranya dapat mempergunakan sekaligus kepala dan tangannya. Disini dimaksudkan bahwa selain memberikan ilmu pengetahuan, negara juga membuat warganya kompeten dalam teknologi, ketrampilan dan kemampuan entrepreneur (Olanipekun, Brimah, 2015). Berdasarkan data dari Badan Pusat Statistik Nasional bahwa tingkat pengangguran yang ada di Indonesia sebagai berikut :

Grafik 1.1

Tingkat Pengangguran Berpendidikan Diploma dan Sarjana

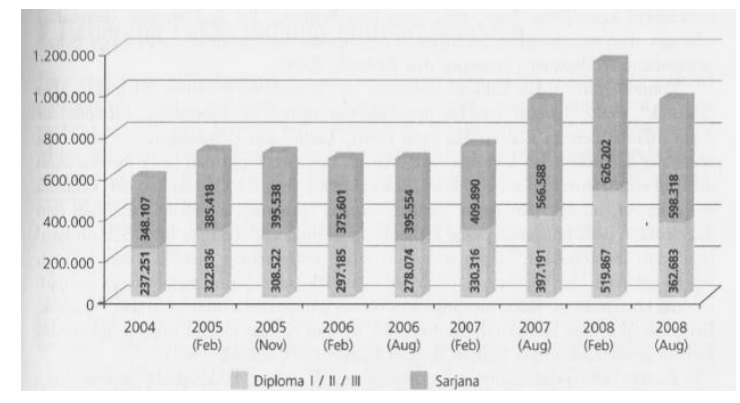

Sumber: BPS (dalam Kodrat dan Christina 2015;41) 
Fatos Bektos (2011) menyatakan bahwa untuk dapat menumbuhkan entrepreneur yang luas dan pesat, maka sangat perlu dilakukan suatu penelitian untuk mendefinisikan dari mana muncul keinginan pada seseorang untuk melakukan kegiatan entrepreneur.Salah satukarakteristik khas seorang entrepreneur adalah kemampuan untuk mengenali sebuah ide baru dan meneliti kelayakan dari gagasan ini beserta faktor resiko dan kemungkinan kegagalan yang berkaitan dengan lingkungan ekonomi dan sosial serta politik dimana ide tersebut akan diterapkan.

Pendidikan kewirausahaan akan mampu menumbuhkan minat mahasiswa berwirausaha jika mata kuliah kewirausahaan mampu menambah pengetahuan mahasiswa mengenai seluk-beluk bisnis baik mengenai softskill maupun hard skill sehingga mahasiswa mampu memanfaatkan peluang yang ada di sekitarnya dalam menciptakan usaha sendiri setelah lulus maupun saat masihkuliah.

Lestari\&Wijaya (2012) mengemukakan bahwa sikap, perilaku, dan minat kearah kewirausahaan seorang mahasiswa dipengaruhi oleh pertimbangan atas berbagai aspek mengenai pilihan karir sebagai wirausahawan. Pendidikan kewirausahaan juga dapat menjadi salah satu pilihan karir selain pilihan karir menjadi pegawai swasta, PNS, atau pegawai BUMN.

Kodrat dan Christina (2015) mengemukakan bahwa isu ekonomi tentang semakin berkurangnya kesempatan bekerja, tingginya jumlah pengangguran termasuk di dalamnya pengangguran berpendidikan diploma dan sarjana mendorong lahirnya entrepreneur muda dalam menciptakan lapangan kerja.

Mahasiswa diarahkan untuk memiliki orientasi berfikir ke masa depan. Sebagai calon sarjana, mahasiswa dibekali pengetahuan, keterampilan dan sikap sebagai seorang professional dibidangnya. Dalam hal ini peran dosen kewirausahaan menjadi penting bukan hanya memberikan pengetahuan berwirausaha, namun memberikan nilai-nilai karakter positif dalam kewirausahaan. Dosen dalam memberikan mata kuliah kewirausahaan diharapkan mampu menumbuhkan minat mahasiswa untuk berwirausaha, sehingga orientasi berfikirnya bukan lagi sebagai pencari kerja melainkan menciptakan lapangan kerja.

Demikian pula realita yang ada sekarang ini, lulusan perguruan tinggi lebih memilih untuk berkarier di perusahaan-perusahaan dibandingkan memilih untuk 
menjadi seorang entrepreneur sehingga dengan tidak tertampungnya jumlah lulusan perguruan tinggi tersebut terciptalah banyak pengangguran.

\section{Rumusan Masalah}

Berdasarkan uraian diatas maka peneliti menfokuskan masalah yang diteliti dan dianalisis dalam bentuk pertanyaan sebagai berikut:

1) Bagaimana pengaruh Pendidikan Kewirausahaan terhadap Minat Berwirausaha mahasiswa Fakultas Ekonomi Universitas Semarang?

2) Bagaimana pengaruh Motivasi Berprestasi Terhadap Minat Berwirausaha Mahasiswa Fakultas Ekonomi Universitas Semarang.

\section{Tujuan Penelitian}

Adapun tujuan dari penelitian ini adalah :

1) Untuk mengetahui pengaruh Pendidikan Kewirausahaan terhadap Minat Berwirausaha mahasiswa Fakultas Ekonomi Universitas Semarang

2) Untuk mengetahui Motivasi Berprestasi Terhadap Minat Berwirausaha Mahasiswa Fakultas Ekonomi Universitas Semarang.

\section{TINJAUAN PUSTAKA}

\section{Pendidikan Kewirausahaan}

Nurhayati (2011) mengemukakan bahwa pembelajaran di perguruan tinggi lebih banyak menekankan transformasi pengetahuan kepada mahasiswa daripada mentransformasikan keterampilan yang dibutuhkan oleh mahasiswa. Padahal proses belajar seperti itu akan menjadikan mahasiswa kurang kreatif, miskin ide dan belajar menjadi "kering tidak bermakna" karena mahasiswa "dipaksa" lebih banyak bahan atau informasi yang diberikan dosen(learning based content) yang akan meminimalisir peran, kreativitas, dan tanggung jawab mahasiswa.

\section{Motivasi Berprestasi}

Djaali (2014) mengemukakan bahwa motivasi berprestasi merupakan kondisi fisiologis dan psikologis yang terdapat dalam diri siswa yang mendorongnya untuk melakukan aktivitas tertentu guna mencapai tujuan tertentu. 


\section{Minat Berwirausaha}

Djaali (2014) mengemukakan bahwa minat adalah rasa lebih suka dan rasa ketertarikan pada suatu hal atau aktivitas, tanpa ada yang menyuruh.

\section{METODE PENELITIAN}

\section{Lokasi Penelitian}

Penelitian dilakukan di lingkungan Universitas Semarang

\section{Kerangka Konseptual}

Adapun kerangka konseptual penelitian ini adalah sebagai berikut :

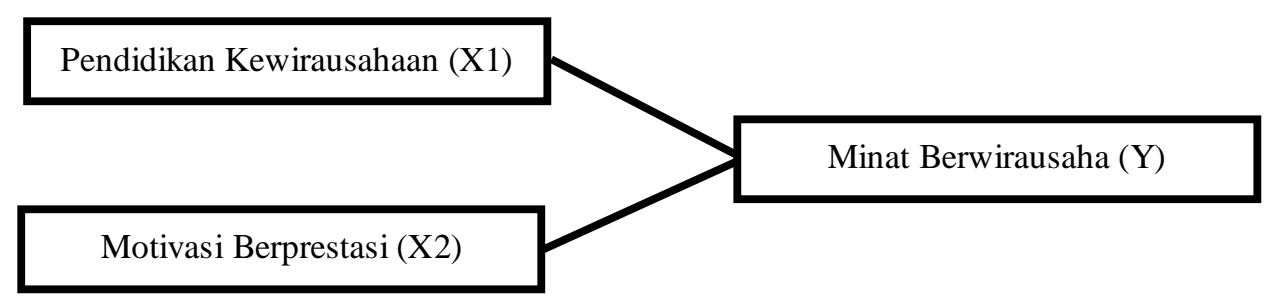

\section{Populasi dan Sampel}

\section{Populasi}

Populasi adalah mahasiswa kelas sore Fakultas Ekonomi Manajemen Semester II angkatan 2017/2018 sebanyak 314 mahasiswa Universitas Semarang

\section{Sampel}

Dalam menentukan sampel digunakan rumus Slovin menurut Husein Umar (2010), sebagai berikut:

$$
\begin{aligned}
n & =\frac{N}{1+N e^{2}} \\
n & =\frac{314}{1+314(0.05)^{2}} \\
n & =175,9 \text { dibulatkan menjadi } 176 \text { responden }
\end{aligned}
$$

Keterangan :

n : ukuran sampel

$\mathrm{N}$ : ukuran populasi

e : presentasi kelonggaran penelitiankarena kesalahan pengambilan sampel yang masih dapat ditolelir $(\mathrm{e}=0,05)$. 


\section{Jenis Sumber Data}

Adapun sumber data dalam penelitian ini ada 2 macam sumber data yaitu :

a. Data Primer

Data yang diperoleh secara langsung dari obyek yang diteliti, dalam hal ini adalah mahasiswakelas sore semester II yang berada di Fakultas Ekonomi Universitas Semarang.

b. Data Sekunder

Data yang diperoleh secara tidak langsung, untuk mendukung penelitian ini penulis mendapatkan dari literatur, diktat, buku yang berkaitan dengan penelitian.

\section{Definisi Operasional dan Indikator Penelitian}

\section{Pendidikan Kewirausahaan}

Sumiharsono (2014) mengemukakan bahwa pendidikan adalah usaha melakukan analisa yang cermat dapatmemperkaya pemahaman terhadap ilmu pengetahuan dan membantu memperoleh, konsep teori, dan praktik yang lebih kuat serta sarat nilai. Indikatornya meliputi :
a. Berani mengambil resiko
b. Proaktif
c. Inovasi

\section{Motivasi Berprestasi}

Djaali (2014) mengemukakan bahwa motivasi berprestasi merupakan kondisi fisiologis dan psikologis yang terdapat dalam diri siswa yang mendorongnya untuk melakukan aktivitas tertentu guna mencapai tujuan tertentu. Indikatornya meliputi :
a. Upaya untuk berhasil.
b. Keterlibatan ego individu dalam suatutugas
c. Harapan suatu tugas yang terlihat oleh tanggapnya subyek
d. Motifuntuk mengatasi rintangan.

\section{Minat Berwirausaha}

Khairani (2014) mengemukakan bahwa pengertian minat sebagai hasil interaksi dan belajar dengan lingkungannya yang melahirkan energi yang luar biasa untuk berjuang mendapatkannya. Indikatornya meliputi :

a. Faktor lingkungan 

b. Motiv sosial
c. Faktor emosional

\section{Jenis Penelitian}

Berdasarkan tujuan yang hendak dicapai, maka pendekatan penelitian menggunakan pendekatankuantitatif.

\section{Metode Pengumpulan Data}

Metode pengumpulan data menggunakan kuesioner, observasi dan wawancara.Data primer pada penelitian ini dikumpulkan dengan menggunakan instrumen kuesioner (angket).Penyebaran kuisioner merupakan metode pengumpulan data yang dilakukan dengan mengajukan daftar pertanyaan secara tertulis kepada responden.Pertanyaan yang diajukan adalah pertanyaan secara logis berhubungan dengan masalah penelitian.Untuk mengukur variabel yang ada digunakan skala-skala Likert, dengan skala 1 sampai dengan 5 .

\section{Metode Analisis Data}

Analisis data dalam penelitian ini menggunakan Analisis Regresi Linier Berganda dan uji asumsi klasik dengan menggunakan aplikasi program SPSS ver 18 forwindows.. Persamaan regresi linear berganda sebagai berikut:

$$
\mathrm{Y}^{\prime}=\mathrm{a}+\mathrm{b} 1 \mathrm{X} 1+\mathrm{b} 2 \mathrm{X} 2+\ldots . .+\mathrm{bnXn}
$$

Keterangan:

$$
\begin{aligned}
& \mathrm{Y}^{\prime}=\text { Variabeldependen } \\
& \mathrm{X} 1 \text { dan } \mathrm{X} 2=\text { Variabel independen } \\
& \mathrm{a}=\text { Konstanta (nilai } \mathrm{Y}^{\prime} \text { apabila } \mathrm{X} 1, \mathrm{X} 2 \ldots . \mathrm{Xn}=0 \text { ) } \\
& \mathrm{b}=\text { Koefisien regresi } \\
& \quad \text { (nilai peningkatanataupunpenurunan) }
\end{aligned}
$$

\section{Teknik Pengambilan Sampel}

Teknik pengambilan sampel Purposive random sampling yaitu tehnik yang digunakan oleh peneliti dengan pertimbangan tertentu (dengan berbekal pengetahuan tentang populasinya) untuk memilih anggota-anggota sampel (Silalahi, 2003).Penentuan sampel/responden secara Purposive random sampling sehingga diperoleh sampel 50 orang mahasiswa. Kriteria penelitian ini ditetapkan berdasarkan: 
a. Mahasiswa sedang menempuh mata kuliah kewirausahaan pada semester II (genap)

b. Usia responden 18-25 tahun.

\section{PEMBAHASAN}

\section{Uji Validitas dan Reliabilitas Instrumen}

\section{Uji Validitas}

Uji validitas menguji masing-masing variabel yang digunakan dalam penelitian ini.Keseluruhan variabel penelitian memuat 10 pernyataan yang harus dijawab oleh responden. Adapun kriteria yang digunakan dalam menentukan valid tidaknya pernyataan yang digunakan dalam penelitian ini adalah sebagai berikut: tingkat kepercayaan $=95 \%(\square=5$ persen $)$, derajat kebebasan $(\mathrm{df})=\mathrm{n}-2$, diperoleh $\mathrm{r}$ tabel $=$ 0,147 (uji dua sisi). Jika $r$ hitung (nilai pearson correlation) lebih besar dari $r$ tabel dan nilai r positif, maka butir pernyataan dikatakan valid (Ghozali, 2005).

Tabel 4.18. Hasil Uji Validitas

\begin{tabular}{|c|c|c|c|c|c|}
\hline Variabel & Indikator & $\begin{array}{c}\text { Kode } \\
\text { Item }\end{array}$ & r hitung & r tabel & Keterangan \\
\hline Pendidikan & 1 & X1.1 & 0,942 & 0,147 & Valid \\
Kewirausahaan & 2 & X1.2 & 0,891 & 0,147 & Valid \\
& 3 & X1.3 & 0,907 & 0,147 & Valid \\
\hline \multirow{3}{*}{ Motivasi Berprestasi } & 1 & X2.1 & 0,885 & 0,147 & Valid \\
& 2 & X2.2 & 0,847 & 0,147 & Valid \\
& 3 & X2.3 & 0,746 & 0,147 & Valid \\
\hline \multirow{2}{*}{ Minat Berwirausaha } & 1 & X2.4 & 0,811 & 0,147 & Valid \\
& 2 & X3.2 & 0,822 & 0,147 & Valid \\
& 3 & X3.3 & 0,749 & 0,147 & Valid \\
\hline
\end{tabular}

Sumber: Data primer yang diolah, 2018

Berdasarkan Tabel 4.18, diketahui bahwa nilai $\mathrm{r}$ hitung dari semua indikator lebih besar dari nilai $r$ tabel. Oleh karena itu dapat disimpulkan bahwa semua indikator dalam penelitian ini adalah valid.

\section{Uji Reliabilitas}

Reliabilitas adalah alat untuk mengukur suatu kuesioner yang merupakan alat pengukuran konstruk atau variabel.Kuesioner dikatakan reliabel atau handal jika jawaban seseorang, terhadap pernyataan tersebut konsisten atau stabil dari waktu ke waktu (Ghozali, 2005).Uji reliabilitas adalah tingkat kestabilan suatu alat pengukur 
dalam mengukur suatu gejala/kejadian.Semakin tinggi reliabilitas suatu alat pengukur, semakin stabil pula alat pengukur tersebut. Suatu konstruk dikatakan reliabel jika memberikan nilai Cronbach Alpha > 0,60 (Ghozali, 2005).

\section{Tabel 4.19. Hasil Uji Reliabilitas}

\begin{tabular}{|l|c|c|}
\hline \multicolumn{1}{|c|}{ Variabel } & Cronbach Alpha & Status \\
\hline Pendidikan Kewirausahaan & 0,918 & Reliabel \\
\hline Motivasi Berprestasi & 0,842 & Reliabel \\
\hline Minat Berwirausaha & 0,732 & Reliabel \\
\hline
\end{tabular}

Sumber: Data primer yang diolah, 2018

\section{Uji Asumsi Klasik}

\section{Uji Multikolinieritas}

Uji multikolinieritas bertujuan untuk menguji apakah model regresi ditemukan adanya korelasi antar variabel bebas (independen). Model regresi yang baik seharusnya tidak terjadi korelasi diantara variabel (Ghozali, 2005).

Multikolinieritas dalam model regresi pada penelitian ditentukan berdasarkan nilai VIF (variance inflation factor) dan tolerance. Adapun nilai VIF dapat dilihat pada Tabel 4.20 di bawah ini:

Tabel 4.20. Nilai Tolerance dan VIF

\begin{tabular}{|l|c|c|}
\hline \multicolumn{1}{|c|}{ Variabel } & Tolerance & VIF \\
\hline Pendidikan Kewirausahaan & 0,217 & 4,598 \\
\hline Motivasi Berprestasi & 0,217 & 4,598 \\
\hline
\end{tabular}

Sumber: Data primer yang diolah, 2018

Dari Tabel 4.20 terlihat bahwa tidak ada variabel yang memiliki nilai VIF lebih besar dari 10 dan nilai tolerance yang lebih kecil dari 0,1 yang berarti bahwa tidak terdapat korelasi antar variabel bebas. Sehingga dapat disimpulkan bahwa tidak terdapat multikolinieritas antar variabel bebas dalam model regresi ini.

\section{Uji Heteroskedastisitas}

Uji heteroskedastisitas bertujuan untuk menguji apakah data dalam model regresi terjadi ketidaksamaan variance dari residual satu pengamatan ke pengamatan lain. Uji heteroskedastisitas menghasilkan grafik pola penyebaran titik (scatter plot) seperti tampak pada Gambar 4.9 berikut: 


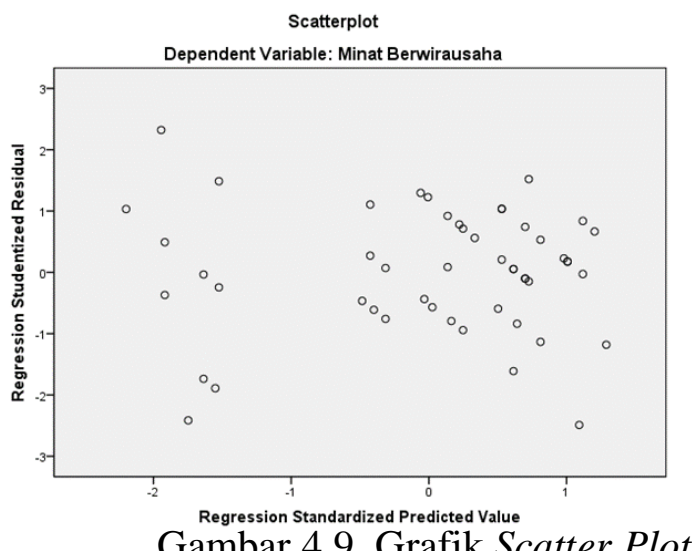

Gambar 4.9. Grafik Scatter Plot

Dari grafik scatter plot dapat dilihat bahwa tidak ada pola yang jelas serta titik-titik menyebar di atas dan di bawah angka 0 (nol) pada sumbu Y, maka tidak terjadi heteroskedastisitas.

\section{Uji Normalitas}

Uji normalitas bertujuan untuk menguji apakah dalam model regresi, variabel pengganggu atau residual memiliki distribusi normal atau tidak. Uji normalitas menghasilkan grafik normal probability plot yang tampak pada Gambar 4.10 dan untuk mengetahui secara detail apakah data tersebut berdistribusi normal, maka dapat dilihat pada Uji Kolmogrov-Smirnov pada Tabel 4.21 berikut:

Gambar 4.10.

\section{Grafik Normal Probability Plot}

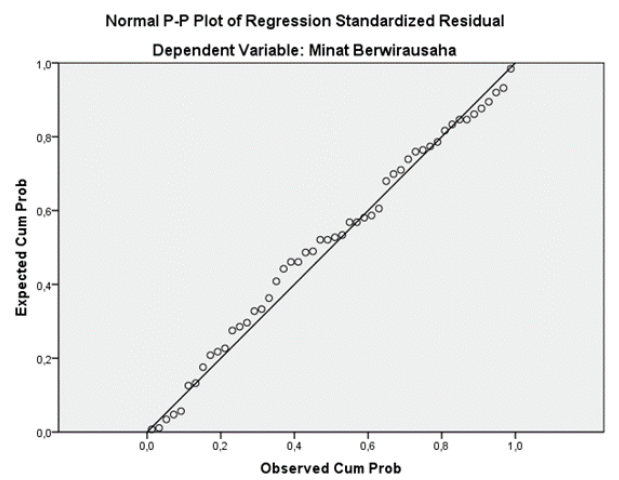

Sumber: Data primer yang diolah, 2018

Gambar 4.10 menunjukkan point-point data yang sebenarnya bergerak searah dan di seputar garis diagonal, sehingga bisa disimpulkan bahwa asumsi normalitas pada model regresi ini terpenuhi 
Tabel 4.21

Uji Kolmogorov-Smirnov

One-Sample Kolmogorov-Smirnov Test

\begin{tabular}{|ll|r|}
\hline & & \multicolumn{2}{|c|}{$\begin{array}{c}\text { Unstandardized } \\
\text { Residual }\end{array}$} \\
\hline $\mathrm{N}$ & Mean & 176 \\
Normal Parameters ${ }^{\mathrm{a}, \mathrm{b}}$ & Std. Deviation &, 0000000 \\
& Absolute & 1,19708662 \\
Most Extreme Differences & Positive &, 081 \\
& Negative &, 047 \\
Kolmogorov-Smirnov Z & &,- 081 \\
Asymp. Sig. (2-tailed) & &, 572 \\
\end{tabular}

a. Test distribution is Normal.

b. Calculated from data.

Sumber: Data primer yang diolah, 2018

Dari tabel 4.21 di atas, terlihat bahwa Asymp Sig $(0,899)>0,05$, sehingga dapat dikatakan bahwa data terdistribusi normal

\section{Analisis Regresi Linier Berganda}

Analisis regresi linier berganda yang telah dilakukan diperoleh koefisien regresi, nilai t hitung dan tingkat signifikansi sebagaimana ditampilkan pada Tabel 4.22 sebagai berikut:

Tabel 4.22 Hasil Uji Regresi Linier Berganda Coefficients $^{\mathrm{a}}$

\begin{tabular}{|c|c|c|c|c|c|}
\hline \multirow[t]{2}{*}{ Model } & \multicolumn{2}{|c|}{$\begin{array}{c}\text { Unstandardized } \\
\text { Coefficients }\end{array}$} & \multirow{2}{*}{$\begin{array}{c}\begin{array}{c}\text { Standardized } \\
\text { Coefficients }\end{array} \\
\text { Beta }\end{array}$} & \multirow[b]{2}{*}{$\mathrm{t}$} & \multirow[b]{2}{*}{ Sig. } \\
\hline & $\mathrm{B}$ & Std. Error & & & \\
\hline 1 (Constant) & 2,535 &, 771 & & 3,290 &, 002 \\
\hline $\begin{array}{l}\text { Pendidikan } \\
\text { Kewirausahaan }\end{array}$ & ,427 & ,100 & ,646 & 4,283 &, 000 \\
\hline Motivasi Berprestasi & ,185 & ,111 & ,251 & 1,666 & ,102 \\
\hline
\end{tabular}

a. Dependent Variable: Minat Berwirausaha

Sumber: Data primer yang diolah, 2018

Dari hasil tersebut, persamaan regresi yang diperoleh adalah:

$\mathrm{Y}=0,646 \mathrm{X} 1+0,251 \mathrm{X} 2+\mathrm{e}$

Persamaan regresi berganda tersebut dijelaskan sebagai berikut:

1. Variabel Pendidikan Kewirausahaan (X1) mempunyai pengaruh positif terhadap Minat Berwirausaha (Y) dengan nilai 0,646; artinya semakin baik pendidikan kewirausahaan di universitas semarang maka minat berwirausaha semakin meningkat. 
2. Variabel Motivasi Berprestasi (X2) mempunyai pengaruh positif terhadap Minat Berwirausaha (Y) dengan nilai 0,251; artinya semakin baik motivasi berprestasi di universitas semarang maka minat berwirausaha semakin meningkat.

\section{Uji Koefisien Determinasi (R2)}

Koefisien Determinasi (R2) pada intinya mengukur seberapa jauh kemampuan model dalam menerangkan variasi variabel dependen.Nilai koefisien determinasi adalah antara nol dan satu (Ghozali, 2005). Nilai koefisien determinasi dapat dilihat Tabel 4.23 di bawah ini:

Tabel 4.23 Hasil Uji Koefisien Determinasi $\left(\mathbf{R}^{2}\right)$

\section{Model Summary ${ }^{b}$}

\begin{tabular}{|c|c|r|r|r|}
\hline Model & $\mathrm{R}$ & R Square & Adjusted R Square & Std. Error of the Estimate \\
\hline dimension0 1 &, $876^{\mathrm{a}}$ &, 767 &, 758 & 1,222 \\
\hline
\end{tabular}

a. Predictors: (Constant), Motivasi Berprestasi, Pendidikan Kewirausahaan

b. Dependent Variable: Minat Berwirausaha

Sumber: Data primer yang diolah, 2018

Dari Tabel 4.23 terlihat tampilan output SPSS model summary besarnya adjusted R square adalah 0,758 . Hal ini berarti hanya $75,8 \%$ variasi minat berwirausaha (Y) dapat dijelaskan oleh variabel-variabel independen di atas. Sedang sisanya $(100 \%-75,8 \%=$ $24,2 \%$ ) dijelaskan oleh sebab-sebab lain di luar model.

\section{Goodness of Fit Test}

Ketepatan fungsi regresi sampel dalam menaksir nilai aktual dapat dinilai dengan goodness of fit test-nya.Secara statistik setidaknya ini dapat diukur dari nilai koefisien determinasi, nilai statistik F dan nilai statistik t (Ghozali, 2005).

\section{Uji F}

Uji $F$ digunakan untuk menguji ada tidaknya pengaruh variabel-variabel independen terhadap variabel dependen secara simultan (bersama-sama).

Tabel 4.24 Hasil Uji F

ANOVA $^{\mathrm{b}}$

\begin{tabular}{|c|c|c|c|c|c|}
\hline Model & Sum of Squares & $\mathrm{df}$ & Mean Square & $\mathrm{F}$ & Sig. \\
\hline 1 Regression & 231,782 & 2 & 115,891 & 77,571 &, $000^{\mathrm{a}}$ \\
\hline Residual & 70,218 & 173 & 1,494 & & \\
\hline Total & 302,000 & 175 & & & \\
\hline
\end{tabular}

a. Predictors: (Constant), Motivasi Berprestasi, Pendidikan Kewirausahaan

b. Dependent Variable: Minat Berwirausaha

Sumber: Data primer yang diolah, 2018 
Berdasarkan uji Anova atau F test, maka dapat diperoleh $\mathrm{F}$ hitung sebesar 77,571 dengan tingkat signifikansi 0,000. Oleh karena probabilitas jauh lebih kecil daripada $0,05(0,000<0,05)$ dan $\mathrm{F}$ hitung lebih besar daripada $\mathrm{F}$ tabel $(77,571>3,20)$ maka dapat dinyatakan bahwa variabel independen yang meliputi Pendidikan Kewirausahaan (X1), dan Motivasi Berprestasi (X2), secara simultan atau bersama-sama mempengaruhi variabel Minat Berwirausaha (Y) secara signifikan.

\section{Uji T}

Uji t yaitu suatu uji untuk mengetahui signifikansi pengaruh variabel bebas secara parsial atau individual terhadap variabel terikat.

Tabel 4.25 Hasil Uji T

\section{Coefficients $^{\mathrm{a}}$}

\begin{tabular}{|c|c|c|c|c|c|}
\hline \multirow[t]{2}{*}{ Model } & \multicolumn{2}{|c|}{$\begin{array}{c}\text { Unstandardized } \\
\text { Coefficients }\end{array}$} & \multirow{2}{*}{$\begin{array}{c}\text { Standardized } \\
\text { Coefficients }\end{array}$} & \multirow[b]{2}{*}{$\mathrm{t}$} & \multirow[b]{2}{*}{ Sig. } \\
\hline & B & Std. Error & & & \\
\hline (Constant) & 2,535 &, 771 & & 3,290 &, 002 \\
\hline $\begin{array}{l}\text { Pendidikan } \\
\text { Kewirausahaan }\end{array}$ & ,427 & , 100 & 646 & 4,283 & ,000 \\
\hline Motivasi Berprestasi & 185 & ,111 & ,251 & 1,666 & ,102 \\
\hline
\end{tabular}

a. Dependent Variable: Minat Berwirausaha

Sumber: Data primer yang diolah, 2018

Dari Tabel 4.25 terlihat bahwa:

a. Dari hasil perhitungan SPSS, dapat diketahui signifikansi variabel pendidikan kewirausahaan sebesar 0,000. Oleh karena probabilitas di bawah 0,05 maka koefisien regresi dari pendidikan kewirausahaan adalah signifikan, sedangkan $\mathrm{t}$ hitung $(4,283)$ lebih besar daripada t tabel $(2,011)$ maka Ho ditolak dan Ha diterima. Hal ini berarti bahwa pendidikan kewirausahaan berpengaruh positif terhadap minat berwirausaha di universitas semarang. Berarti hipotesis yang berbunyi: pendidikan kewirausahaan berpengaruh terhadap minat berwirausaha adalah benar.

b. Dari hasil perhitungan SPSS, dapat diketahui signifikansi variabel Motivasi Berprestasi sebesar 0,102. Oleh karena probabilitas di atas 0,05 maka koefisien regresi dari motivasi berprestasi adalah tidak signifikan, sedangkan $t$ hitung $(1,666)$ lebih kecil daripada t tabel $(2,011)$ maka Ho diterima dan Ha ditolak. Hal ini berarti bahwa motivasi berprestasi tidak berpengaruh positif terhadap minat berwirausaha 
di universitas semarang. Berarti hipotesis yang berbunyi: Motivasi Berprestasi berpengaruh terhadap Minat Berwirausaha adalah tidak benar.

\section{Pembahasan}

Berdasarkan hasil pengujian goodness of fit, dapat disimpulkan bahwa variabel-variabel independen dalam penelitian ini mampu menerangkan mengenai $76,7 \%$ persen variasi minat berwirausaha. Sedangkan sisanya, 23,3\% dipengaruhi oleh sebab lain di luar model. Dari kedua variabel independen yang diuji secara individual yang paling dominan dalam mempengaruhi minat berwirausaha di universitas semarang adalah pendidikan kewirausahaan (dengan koefisien 0,646). Variabel kedua yang dominan mempengaruhi minat berwirausaha di universitas semarang adalah motivasi berprestasi (dengan koefisien 0,251). Hanya variabel pendidikan kewirausahaan yang berpengaruh positif signifikan terhadap minat berwirausaha di universitas semarang.

Variabel Pendidikan Kewirausahaan dalam penelitian ini berpengaruh positif dan signifikan terhadap minat berwirausaha di universitas semarang. Dalam penelitian ini, indikator yang digunakan untuk mengukur pendidikan kewirausahaan adalah: Berani Mengambil Resiko, Proaktif dan Inovasi. Masing-masing indikator mendapat tanggapan positif dari 176 responden yang diteliti. Berdasarkan alasan dan tanggapan responden yang sudah dijelaskan, dapat disimpulkan bahwa pendidikan kewirausahaan mempengaruhi minat berwirausaha di universitas semarang.

Temuan penelitian ini konsisten dengan temuan penelitian vera firdaus (2014) meneliti tentang pengaruh Pendidikan Kewirausahaan dan Motivasi Berprestasi Terhadap Minat Berwirausaha Mahasiswa Fakultas Ilmu Pendidikan IKIP PGRI Jember dengan hasil yang menunjukkan bahwa pendidikan kewirausahaan berpengaruh signifikan terhadap minat berwirausaha. Maka dapat ditarik kesimpulan bahwa pendidikan kewirausahaan mempunyai pengaruh terhadap minat berwirausaha.ini sesuai dengan teori yang dikemukakan oleh Chrismardani. (2013) mengemukakan bahwa desainpembelajaran kewirausahaan berorientasi untuk menghasilkan business entrepreneur terutama yang menjadi owner entrepreneur atau calon wirausaha mandiri yang mampu mendirikan, memiliki dan mengelola perusahaan serta dapat memasuki dunia bisnis dan dunia industri secara profesional yang di dalamnya memuat aspek-aspek teori, praktek danimplementasi. 
Variabel motivasi berprestasi berpengaruh positif tidak signifikan terhadap minat berwirausaha di universitas semarang. Dalam penelitian ini variabel motivasi berprestasi menggunakan indikator: Upaya untuk berhasil., Keterlibatan ego individu dalam suatu tugas, Harapan suatu tugas yang terlihat oleh tanggapnya subyek dan Motif untuk mengatasi rintangan. Masing-masing indikator mendapat tanggapan positif dari 50 responden yang diteliti.Hasil penelitian menunjukkan bahwa indikator dalam motivasi berprestasi tersebut memiliki pengaruh positif tidak signifikan terhadap minat berwirausaha. Berdasarkan alasan dan tanggapan responden yang sudah dijelaskan, dapat disimpulkan bahwa motivasi berprestasi mempengaruhi mahasiswa secara positif tidak signifikan dalam minat berwirausaha di universitas semarang. Temuan penelitian ini konsisten dengan temuan penelitian Rosmiati.Junias, Donny Teguh Santosa. Munawar.(2015). meneliti tentang motivasi berprestasi terhadap minat berwirausaha yang hasilnya menunjukan bahwa variabelsikap, motivasi dan minat berwirausaha tidak berpengaruh signifikan terhadap minat mahasiswa berwirausaha. Mahasiswa Jurusan Akuntansi semester satu cenderung kurang berminat berwirausaha, karena sebagian besar mahasiswa belum memahami wirausaha. Beberapa sikap, motivasi dan minat mahasiswa berwirausaha dipengaruhi ketidakpahaman menjalankan usaha Temuan penelitian ini tidak sesuai dengan teori yang dikemukakan Djaali (2014) mengemukakan bahwa motivasi berprestasi merupakan kondisi fisiologis dan psikologis yang terdapat dalam diri siswa yang mendorongnya untuk melakukan aktivitas tertentu guna mencapai tujuan tertentu..

\section{Implikasi Manajerial}

Pendidikan Kewirausahaan berpengaruh terhadap Minat Berwirausaha, apabila pendidikan kewirausahaan yaitu : berani mengambil resiko. Proaktif dan inovasi. Berdasarkan hasil uji validasi untuk setiap indikator pendidikan kewirausahaan dari urutan terkecil sampai dengan urutan terbesar adalah :

1. Proaktif, dengan $r$ hitung 0,891

2. Inovasi, dengan $r$ hitung 0,907 .

3. Berani Mengambil Resiko dengan $r$ hitung 0,942

Dengan demikian nilai $r$ hitung yang paling kecil adalah proaktif, dengan $r$ hitung 0,891, sebenarnya nilai 0,891 tidak begitu kecil akan tetapi di dalam variabel dan 
indikator ini tetaplah harus bisa kita cermati mengingat indikator ini adalah proaktif, yang bisa saja nilainya fluktuatif mengenai proaktif ini sebaiknya pihak pengajar memberikan tugas kelompok dengan jelas dan menghargai setiap tugas yang telah diselesaikan mahasiswa agar mahasiswa bisa lebih proaktif dalam berdiskusi di dalam maupun diluar kampus. Nilai $r$ hitung yang tinggi adalah Berani Mengambil Resiko sebesar 0.942, untuk itu perlu dipertahankan agar dengan saran untuk perbaikan tersebut mahasiswa bisa lebih baik lagi dalam meningkatkan prestasi belajar kewirausahaannya. Indikator lain seperti, inovasi dengan $r$ hitung 0,907 perlu ditingkatkan agar mahasiswa bisa lebih baik untuk menghasilkan inovasi yang lebih baik dengan melakukan kegiatan lomba enterpreuner kreatif di kampus.

Motivasi Berprestasi tidak berpengaruh terhadap minat berwirausaha, apabila motivasi berprestasi yaitu : Upaya untuk berhasil, Keterlibatan ego individu dalam suatu tugas, Harapan suatu tugas yang terlihat oleh tanggapnya subyek dan Motif untuk mengatasi rintangan Berdasarkan hasil uji validasi untuk setiap indikator Stress kerja dari urutan terkecil sampai dengan urutan terbesar adalah :

1. Harapan suatu tugas yang terlihat oleh tanggapnya subyek, dengan $r$ hitung 0,746 .

2. Motif untuk mengatasi rintangan, dengan $r$ hitung 0,811 .

3. Keterlibatan ego individu dalam suatu tugas, dengan $r$ hitung 0,847

4. Upaya untuk berhasil, dengan $r$ hitung 0,885

Dengan demikian nilai $r$ hitung yang paling kecil adalah Harapan suatu tugas yang terlihat oleh tanggapnya subyek, dengan $r$ hitung 0,746 , sebaiknya mahasiswa lebih diberikan suatu pelatihan softskill untuk lebih jelas dalam melihat potensi yang ada di dalam dirinya, Nilai $r$ hitung yang tinggi adalah Upaya untuk berhasil 0.885, untuk itu perlu dipertahankan agar dengan usaha tersebut mahasiswa bisa lebih baik untuk meningkatkan soft skillnya. Indikator lain, Motif untuk mengatasi rintangan dan Keterlibatan ego individu dalam suatu tugas dengan $r$ hitung 0,811 dan 0,847, perlu dievaluasi dengan baik. 


\section{PENUTUP}

\section{Simpulan}

Berdasarkan penelitian tentang Pengaruh pendidikan kewirausahaan dan motivasi berprestasi terhadap minat berwirausaha mahasiswa fakultas ekonomi Universitas Semarang, maka dari penelitian tersebut hasil yang diperoleh adalah sebagai berikut:

1. Berdasarkan hasil pengujian goodness of fit, dapat disimpulkan bahwa variabel-variabel independen dalam penelitian ini mampu menerangkan mengenai $75,8 \%$ persen variasi minat berwirausaha. Sedangkan sisanya, $24,2 \%$ dipengaruhi oleh sebab lain di luar model. Dari kedua variabel independen yang diuji secara individual yang paling dominan dalam mempengaruhi minat berwirausaha di universitas semarang adalah pendidikan kewirausahaan (dengan koefisien 0,646). Variabel kedua yang dominan mempengaruhi minat berwirausaha di universitas semarang adalah motivasi berprestasi (dengan koefisien 0,251). Hanya variabel pendidikan kewirausahaan yang berpengaruh positif signifikan terhadap minat berwirausaha di universitas semarang

2. Pendidikan Kewirausahaan berpengaruh terhadap Minat Berwirausaha, apabila pendidikan kewirausahaan yaitu : berani mengambil resiko. Proaktif dan inovasi. Berdasarkan hasil uji validasi untuk setiap indikator pendidikan kewirausahaan dari urutan terkecil sampai dengan urutan terbesar nilai $\mathrm{r}$ hitung yang paling kecil adalah proaktif, dengan $\mathrm{r}$ hitung 0,891, sebenarnya nilai 0,891 tidak begitu kecil akan tetapi di dalam variable dan indicator ini tetaplah harus bisa kita cermati mengingat indicator ini adalah proaktif, yang bisa saja nilainya fluktuatif mengenai proaktif ini sebaiknya pihak pengajar memberikan tugas kelompok dengan jelas dan menghargai setiap tugas yang telah diselesaikan mahasiswa agar mahasiswa bisa lebih proaktif dalam berdiskusi di dalam maupun diluar kampus. Nilai $r$ hitung yang tinggi adalah Berani Mengambil Resiko sebesar 0.942, untuk itu perlu dipertahankan agar dengan saran untuk perbaikan tersebut mahasiswa bisa lebih baik lagi dalam meningkatkan prestasi belajar kewirausahaannya. Indikator lain seperti, inovasi dengan $r$ hitung 0,907 perlu ditingkatkan agar mahasiswa bisa lebih baik untuk menghasilkan inovasi yang lebih baik dengan melakukan kegiatan lomba enterpreuner kreatif di kampus 
3. Motivasi Berprestasi tidak berpengaruh terhadap minat berwirausaha, apabila motivasi berprestasi yaitu : Upaya untuk berhasil, Keterlibatan ego individu dalam suatu tugas, Harapan suatu tugas yang terlihat oleh tanggapnya subyek dan Motif untuk mengatasi rintangan Berdasarkan hasil uji validasi untuk setiap indikator Motivasi Berprestasi dari urutan terkecil sampai dengan urutan terbesar nilai $\mathrm{r}$ hitung yang paling kecil adalah Harapan suatu tugas yang terlihat oleh tanggapnya subyek, dengan $\mathrm{r}$ hitung 0,746, sebaiknya mahasiswa lebih diberikan suatu pelatihan softskill untuk lebih jelas dalam melihat potensi yang ada di dalam dirinya, Nilai $r$ hitung yang tinggi adalah Upaya untuk berhasil 0.885, untuk itu perlu dipertahankan agar dengan usaha tersebut mahasiswa bisa lebih baik untuk meningkatkan soft skillnya. Indikator lain, Motif untuk mengatasi rintangan dan Keterlibatan ego individu dalam suatu tugas dengan $r$ hitung 0,811 dan 0,847, perlu dievaluasi dengan baik.

\section{Saran}

1. Pendidikan Kewirausahaan berpengaruh terhadap Minat Berwirausaha, untuk itu perlu ditingkatkan agar mahasiswa bisa lebih baik untuk menghasilkan inovasi yang lebih baik dengan melakukan kegiatan lomba enterpreuner kreatif di kampus

2. Motivasi Berprestasi tidak berpengaruh terhadap minat berwirausaha, hal ini bisa dijadikan untuk penelitian selanjutnya dengan menambahkan variable yang mempengaruhi minat berwirausaha.

\section{DAFTAR PUSTAKA}

Ahmad, S., Dhiana, P., Warso, M. 2015.Pengaruh Antara Pengetahuan Kewirausahaan, Motif Berprestasi, Kemandirian Pribadi Terhadap Perilaku Kewirausahaan Pedagang di Pasar Tegowanu. Fakultas Ekonomi Universitas Pandanaran Semarang.http://journal.unpad. ac.id/.2015

Alma, Buchari.2009.Kewirausahaan. Edisi Revisi. Bandung: Alfabeta. 
Chidiebere, O.-N., et al. (2014). Youth Unemployment and Entrepreneurship Development: Challenges And Prospects In Nigeria. Kuwait Chapter of the Arabian Journal of Business and Management Review.

Chrismardani, Yustina. 2016. Model Pembelajaran Kewirausahaan Yang Berkelanjutan. Jurnal Eco-Entrepreneur. Fakultas Ekonomi Universitas Trunojoyo. Bangkalan.

Djaali.2014. Psikologi Pendidikan, Cetakan VIII. Jakarta: Bumi Aksara.

Hayatulfajri.2013. Pengaruh Sikap Pada Praktik Kewirausahaan Terhadap Minat Berwirausaha Siswa Kelas X SMKN I Sumedang. Bandung

Khairani,Makmun.2014. PsikologiBelajar.Sleman,Yogyakarta:Aswaja Pressindo.

Kodrat, D.S. Christina, W. 2015.Entrepeneurship Sebuah Ilmu. Jakarta: Erlangga.

Lestari, R.B.,Wijaya, T. 2012.Pengaruh Pendidikan Kewirausahaan Terhadap Minat $\begin{array}{llll}\text { Berwirausaha } & \text { Mahasiswa di STIE } & \text { MDP, } & \text { STMIK }\end{array}$ MDP,danSTIEMUSI.JurnalIlmiahSTIEMDP:ForumBisnisDan Kewirausahaan.

Nurhayati,Eti.2011. PsikologiPendidikanInovatif.CetakanI.Yogyakarta: Pustaka Pelajar.

Olanipekun, W. D., et al. (2015). Entrepreneurial and Vocational Education Revolution : A Catalyst for Sustainable Development. Kuwait Chapter of the Arabian Journal of Business and Management.

Rahmania, M., Efendi, M. Pengaruh Pengetahuan Kewirausahaan, Praktik Kerja Industri dan Motivasi Berprestasi Terhadap Minat Berwirausaha Siswa Kelas XII Kompetensi Keahlian Pemasaran SMK Negeri Bisnisdan Manajemen Kota Padang. Program Magister Pendidikan Ekonomi Universitas Negeri Padang.http://ejournal.unp.ac.id/Juni 2017. 
Rosmiati., Junias, D.T.S., Munawar. Pengaruh Sikap, Motivasi,dan Minat Berwirausaha Siswa Kelas X SMKN I Sumedang. Jurnal Manajemen dan Kewirausahaan.Jurusan Manajemen Fakultas Ekonomi Universitas Pandanaran Semarang.

Sub Direktorat Statistik Pendidikan dan Kesejateraan Sosial. 2014. Statistik Pemuda Indonesia. Badan Pusat Statistik Jakarta Indonesia. ISSN:2086-1028

Sumiharsono, Rudy. 2014. Ekonomi Pendidikan. Jember:STAIN Jember Press.

Vera Firdaus. 2014. Pengaruh Pendidikan Kewirausahaan dan Motivasi Berprestasi Terhadap Minat Berwirausaha Mahasiswa Fakultas Ilmu Pendidikan IKIP PGRI Jember. Airlangga University Press. Volume 14, Nomor 2. ISSN: 1693-8925. 